\title{
NORMAS DE FORMATAÇÃO PARA ENVIO DE ARTIGOS
}

Papel: Formato A4

Margens: Todas as margens $3 \mathrm{~cm}$.

Artigos em Espanhol devem conter título, resumos e palavras-chave em Inglês e Português.

Título: Em Português e Inglês, em sequência. Centralizados, espaço simples, negrito, Calibri 14, em CAIXA ALTA. Espaço entre os títulos e entre o em Inglês e os autores: 1,5, tamanho 12.

Sub-títulos: (O que inicia as partes do texto): em negrito, calibri 12, dois espaços após o item anterior e um espaço antes do parágrafo seguinte. Norma culta da Língua. Usar controle de linhas órfãs e manter com o próximo.

Autor (es): (Não esqueça de suprimir o nome dos autores em "manuscrito" - arquivo que será enviado para avaliação cega): Parágrafo simples: alinhamento à direita. Sem espaço entre dois ou mais autores. Fonte: Calibri 12. Incluir nota biográfica de rodapé com a formação do autor, área de pesquisa; instituição de origem e e-mail (Calibri 10 - justificado).

Resumos: (Obrigatórios no "manuscrito" - arquivo submetido para avaliação): em Português e em Inglês. Um terceiro pode ser enviado em outra língua opcional, com até 800 caracteres (com espaço), em espaço simples, sem citações e parágrafo único. Colocar um espaço simples entre autor e resumo. Fonte: Calibri 12.

Palavras-chave: 3 a 5, em português e outra língua. Começar por letras maiúscula e separadas por pontos. Parágrafo: espaço simples. Fonte: Calibri 12. Seguida do resumo, com espaço. Ex. Escola. Cultura. Inclusão.

Corpo do texto: Parágrafo Justificado; Recuo da primeira linha do parágrafo: 1,5; Fonte: Calibri/ tamanho 12; Espaçamento: 1,5, sem espaço antes ou depois;

Citações: Até 3 linhas, no corpo do texto com aspas. Mais de três linhas: em parágrafo recuado, à direita, em $4 \mathrm{~cm}$ da margem esquerda, espaço simples sem aspas. Incluir um espaço simples antes e depois. Fonte: Calibri /tamanho 11. Seguir Norma ABNT 10520, disponível em https://www.tccmonografiaseartigos.com.br/regras-normas-formatacao-tcc-monografias-artigos-abnt.

Notas no rodapé: Tamanho 10, justificadas. Calibri, espaçamento simples,

Gráficos e Imagens: Incluir numeração e título acima. Incluir fonte abaixo.

Referências: Apenas para autores citados e segundo normas da ABNT, Calibri, tamanho 11, espaço simples, com espaço de uma linha antes de cada obra citada. Justificado.

Arquivo da submissão: Em formato DOC ou ODT, sem autores. Faça a revisão da língua portuguesa.

DICA

Acesse http://revistaleph.uff.br/index.php/REVISTALEPH/about/submissions\#authorGuidelines

Acesse

https://docs.google.com/document/d/19fvyB6mQUbVGrXEvmBNYDaWvoFXVAfHVCmr4asyalTQ/edit?usp= sharing para obter modelo de formatação.

\section{POLÍTICA DE PRIVACIDADE}

Os nomes e endereços informados nesta revista serão usados exclusivamente para os serviços prestados por esta publicação, não sendo disponibilizados para outras finalidades ou a terceiros.

\section{REVISÃO ORTOGRÁFICA EM PORTUGUÊS, INGLÊS, DEMAIS LÍNGUAS E DAS NORMAS DA ABNT}

São responsabilidade dos autores. A revista não cobra taxa, não tem verba para custeio, nem dispõem de profissional da área. Artigos com muitos erros ortográficos serão imediatamente recusados. 